\title{
AS DIFERENTES PERSPECTIVAS DA MEMÓRIA NA OBRA DE JOSÉ LUIS GUERÍN
}

\section{THE DIFFERENT MEMORY PERSPECTIVES IN THE WORK OF JOSÉ LUIS GUERÍN}

Edição v.35 número 3 / 2016-17

Contracampo e-ISSN 2238-2577 Niterói (RJ), v. 35, n. 3

dez/2016-mar/2017

A Revista Contracampo é uma revista eletrônica do Programa de Pós-Graduação em Comunicação da Universidade Federal Fluminense e tem como objetivo contribuir para a reflexão crítica em torno do campo midiático, atuando como espaço de circulação da pesquisa e do pensamento acadêmico.

\section{CRISTIANE FREITAS GUTFREIND}

Professora do Programa de Pós-graduação em Comunicação da PUCRS. Pesquisadora do CNPq. Brasil.

cristianefreitas@pucrs.br

\section{RAFAEL VALLES}

Doutorando do Programa de Pós-graduação em Comunicação da PUCRS. Bolsista da CAPES. Brasil.

ra.valles@hotmail.com

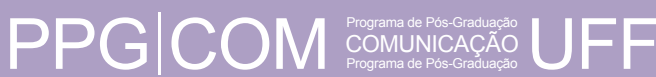

AO CITAR ESTE ARTIGO, UTILIZE A SEGUINTE REFERÊNCIA:

GUTFREIND, Cristiane Freitas; VALLES, Rafael. As diferentes perspectivas da memória na obra de José Luis Guerín. Contracampo, Niterói, v.35, n. 03, dez. 2016/ mar. 2017.

Enviado em: 01 de setembro de 2015 / Aceito em: 18 de abril de 2016. 


\section{Resumo}

Este artigo pretende fazer uma reflexão sobre a obra do realizador espanhol José Luis Guerín, procurando entender como a questão da memória se insere na construção narrativa dos seus filmes. Através de análise fílmica, este artigo parte do pressuposto de que a sua obra não é somente uma fonte importante para o entendimento da memória, mas também um meio que permite identificar a importância que a construção de imagens assume neste processo.

Palavras-chave

comunicação; cinema; memória

\section{Abstract}

This article aims to reflect on the work of spanish director José Luis Guerín, trying to understand how the issue of memory is included in the narrative construction of his films. Through a film analysis, this article assumes that his work is not only an important source for understanding the construction of memory, but also a means to identify the importance that the images take on this process.

\section{Keywords}

communication; cinema; memory 


\section{Introdução}

Para analisar a obra de José Luis Guerín é necessário assumir o desafio de pensar não somente as transitoriedades da representação cinematográfica, mas também a transitoriedade contida na construção da memória. Composta pelo incessante desejo de experimentar distintos suportes técnicos, abordagens narrativas, gêneros cinematográficos, a obra deste cineasta espanhol não se resigna a um método ou a uma classificação categórica. Ainda assim, diante desta diversidade de formas buscada pelo realizador, é possível afirmar que um tema percorre continuamente os seus filmes: materializar em imagens a questão da passagem do tempo e da memória.

Guerín é um entusiasta dos vestígios, dos rastros que testemunham um tempo que se foi ou que está em transformação. Assim iniciou a sua obra com Innisfree (1990) quando decidiu ir à Irlanda quase 40 anos depois das filmagens do filme The quiet man (1952) de John Ford, para ver onde e como se encontravam os habitantes que participaram deste filme. Os vestígios da memória também são o ponto de partida para se pensar Unas fotos en la ciudad de Sylvia (2007), onde o protagonista deste filme, feito a partir de fotografias, decide regressar 22 anos depois a cidade de Estrasburgo para tentar reencontrar uma mulher que havia conhecido. Guerín também flertou com um sentido arqueológico do cinema, ao criar uma história onde supostamente se "encontraram" materiais fílmicos do início do século XX de um personagem intitulado Monsieur Fleury que registrava imagens caseiras da sua família (imagens estas que foram filmadas pelo próprio Guerín). Neste filme de ficção que transita entre um tom documental e poético, o diretor espanhol pensa a materialidade da imagem ao buscar nas ranhuras e deterioração do material em película, fazer uma reflexão sobre o envelhecimento e a corrosão das imagens através do tempo.

A obra de Guerín reflete sobre as limiaridades não somente narrativas entre documentário e ficção, mas também sobre a construção 
da memória, sobre como passado e presente se relacionam entre si. É neste espaço transitório composto por lembranças e esquecimentos, onde a fugacidade do momento presente se mescla com a referência das heranças culturais, que o cineasta espanhol desenvolveu com sensibilidade uma obra que busca compreender as fragilidades es processos limiares pelo qual se constrói a memória.

\section{Os limiares da memória}

Mas afinal, o que pode ser definido como limiar? De que forma é possível utilizar este termo a partir de uma obra cinematográfica como a de Guerín?

Um dos teóricos referentes para se pensar a construção do conceito de limiaridade foi o etnógrafo francês de origem alemã Arnold van Gennep, que procurou analisar este termo através do livro Les rites de passage, publicado em 1909. Com um viés de cunho mais antropológico, Gennep procurou refletir sobre os ritos de passagem que o homem enfrenta no seu processo individual e na sua relação com um meio coletivo. Para isso, dividiu basicamente estes ritos em três categorias: ritos de separação, como por exemplo, as cerimônias relacionadas a funerais; ritos de agregação, como é o caso do matrimônio e ritos de margem, como o processo de gravidez, por exemplo (GENNEP, 2008, p.25).

Dentro deste contexto dos ritos de passagem, Gennep assumiu especial atenção aos casos relacionados aos "ritos de margem", delimitando, assim, o conceito de limiar. Para o autor "passar o limiar, significa agregar-se a um mundo novo" (GENNEP, 2008, p.37). Como parte do processo de margem, Gennep partiu do entendimento de que os "ritos limiares não são ritos de aliança, propriamente dito, mas ritos de preparação para a aliança, precedidos por ritos de preparação à margem" (GENNEP, 2008, p.37-38).

Por último, Gennep dividiu os ritos limiares em três momentos, enquanto "ritos preliminares aos ritos de separação do mundo anterior, 
ritos liminares aos ritos executados durante o estágio de margem e ritos pós-liminares aos ritos de agregação ao mundo novo" (GENNEP, 2008, p.38). Gennep buscou, assim, construir um entendimento sobre o conceito de limiar enquanto pertencente a um rito de passagem, a um momento transitório tendo em vista um processo mais amplo de inserção em determinados grupos e contextos sociais.

No entanto, o que este presente artigo propõe analisar é um entendimento sobre um conceito de limiar que não fique restrito a uma visão de cunho antropológico e a relação que estabelece enquanto rito cerimonial. "O conceito de schwelle, limiar, soleira, umbral, seuil, pertence igualmente ao domínio de metáforas espaciais que designam operações intelectuais e espirituais" (GAGNEBIN, 2014, p.36). Existe um sentido mais subjetivo para se pensar a questão do limiar e que não esteja necessariamente atrelada a um sentido estritamente antropológico. Esse sentido possibilita apenas um ponto de partida para uma reflexão que transcende o entendimento dos ritos de passagem, como um "rito de preparação para uma aliança". O limiar é pensado aqui, também, como a construção de um campo de significações em que o seu sentido transitório e de fluxo o torne algo mais que somente um "caminho de preparação para um outro estágio".

Como afirma Walter Benjamin no seu Projeto Passagens (19271940), livro inacabado, onde o autor procurou realizar uma espécie de collage de citações para refletir, entre outros temas, sobre a significação do limiar, "é necessário distinguir com toda claridade o limiar do limite". O limiar (umbral) é uma zona. O termo "umbralar" implica mudança, transição, marés, e a etimologia não pode deixar passar estes significados (BENJAMIN, 2005, p.495).

Gagnebin realiza, também, uma reflexão que tenta dar sentido a ideia de limiar ponderando diferentes possibilidades:

(O limiar) lembra fluxos e contrafluxos, viagens e desejos. (...) O limiar não significa somente a separação, mas também aponta para um lugar e um tempo intermediários e, nesse sentido, indeterminados, que podem, portanto, ter uma extensão variável, mesmo indefinida. (...) O limiar designa, portanto, essa zona intermediária que a filosofia ocidental - 
bem como o assim chamado senso comum - custa a pensar, pois que é mais afeita às oposições demarcadas e claras (masculino/ feminino, público/privado, sagrado/ profano). (GAGNEBIN, 2014, p.36, 37)

Mas mesmo que Benjamin e Gagnebin procurem distanciar o entendimento do limiar em relação ao limite, classificar o limiar como uma zona inevitavelmente termina estabelecendo uma relação com a esfera dos limites, pelo simples fato de que uma zona em si também se constitui enquanto zona pelos seus limites. É partindo destes questionamentos que nos interessa entender aqui o limiar mais como um estado, um processo, uma dobra, um ponto de inflexão onde os seus movimentos promovem desestabilizações no pensamento, que busque no seus desvios desconstruir uma visão formada por dicotomias. Se a ideia de zona imprime limites ao termo, refletir sobre o limiar enquanto processo contribui para construir um campo de possibilidades para romper limites, atravessar fronteiras, para construir passagens tendo em vista um caminho de descobertas.

Se formos pensar, por exemplo, a questão da memória sobre a perspectiva da sua limiaridade, é possível entender o caráter transitório e frágil que assume um ato de rememoração na busca do indivíduo por lembrar fatos passados.

O limiar é, de maneira mais significativa, o que vacila entre o desaparecimento de algo e sua sobrevida como vestígio. (...) Porque o limiar conecta diversas modalidades de tempo, cujas estratificações se expressam em documentos, monumentos, arquivos, museus, arquitetura, cartazes publicitários. (...) O limiar e as passagens contém, ao mesmo tempo, o dentro e o fora, o antes e o depois. Por isso, "articular historicamente o passado não significa conhecê-lo 'como ele de fato foi'. Significa apoderar-se de uma reminiscência, tal qual ela cintila no momento de um perigo" (MATOS, 2015, p.107, 113).

Assumir as instabilidades de um ato de rememoração é começar a entender as limiaridades contidas dentro do âmbito da memória, enquanto um constante meio transitório onde se constroem a lembrança e o esquecimento, o presente e o passado, assim como o nível consciente e inconsciente na evocação de uma lembrança. "A reevocação não é 
algo passivo (...) Voltar a lembrar implica um esforço deliberado da mente; é uma espécie de escavação ou de busca voluntária entre os conteúdos da alma" (ROSSI, 2010, p.16).

$\mathrm{O}$ ato de rememorar encontra no seu exercício de evocação e na sua impossibilidade de tudo recordar, um caminho para construir a sua limiaridade. Podemos lembrar quais atividades realizamos ontem, mas nossas lembranças já se tornam imprecisas em relação ao que fizemos uma semana atrás. Buscar inspiração em Funes, o memorioso ${ }^{1}$ é nada mais do que constatar a impossibilidade de assumirmos total controle das nossas lembranças. Nessas imperfeições que constroem a memória, resgatar lembranças se torna uma atividade que está muito longe de ser objetiva e simples.

O processo de localização de uma lembrança no passado, por exemplo, não consiste de maneira alguma, como já se falou, em penetrar na massa de nossas lembranças como num saco, para retirar daí lembranças cada vez mais aproximadas, entre as quais irá aparecer a lembrança e localizar. (...) O trabalho de localização consiste, em realidade, num esforço crescente de expansão, através do qual a memória, sempre presente por inteira nela mesma, estende suas lembranças sobre uma superfície cada vez mais ampla e acaba por distinguir assim, num amontoado até então confuso, a lembrança que não encontrava seu lugar. (BERGSON, 2010, p.201) O ato de rememoração é transitório e caótico, transforma-se constantemente de acordo como a nossa subjetividade lidando com a passagem do tempo. Diante desta transitoriedade que opera entre o nível consciente e inconsciente do indivíduo, tornam-se necessário à presença de certos vestígios que auxiliem a evocar lembranças. Neste sentido, objetos, documentos, sensações, fragmentos que remetam ao que se busca lembrar são essenciais neste resgate de lembranças passadas.

Vestígios são signos duplos no sentido de que atrelam indissociavelmente a recordação ao esquecimento. É a clarividência quanto a esse esquecimento embutido

1 Conto do escritor argentino Jorge Luis Borges do livro Ficciones (1944), onde o protagonista possui uma memória prodigiosa que recorda todo tipo de fenômeno ou objeto. 
nos vestígios que rompe a linha contínua da tradição arrancando-a do passado, lançando-a por entre o presente, em direção ao futuro - e, é ela que torna estranho o passado. (ASSMANN, 2011, p.225)

Este fator é importante para entender Unas fotos en la ciudad de Sylvia, filme-diário que Guerín fez como um estudo prévio para realizar o filme En la ciudad de Sylvia. Ao regressar ao bar onde conheceu há 22 anos, Sylvia, o personagem-narrador José Luís, possui duas provas materiais que evocam estas lembranças: o endereço de uma livraria escrita num descansa-copos (Imagem 01) e uma caixa de fósforos do bar. Além desses objetos, somente permaneceram três lembranças: ela estudou alguns meses em Salamanca; ela gostava do som do seu nome em espanhol; ela começou a trabalhar como enfermeira. É através destes vestígios que Guerín estabelece não somente uma busca narrativa, mas também uma forma de encarar o seu ato de rememoração.

Guerín parte desta limiaridade entre lembranças e esquecimentos, entre vestígios e evocações para mostrar a transitoriedade por onde se constrói a memória. Sem estar restrita a conservação do passado, a memória se transforma diante da passagem do tempo. É partindo destas lacunas, que o personagem-narrador decide percorrer sem maiores precisões pelas ruas de Estrasburgo e pelos centros hospitalares da cidade em busca de Sylvia. Durante este processo não existe uma ilusão de encontrá-la, mas a constatação de que as inscrições do tempo neste ato de rememoração tornam esta tarefa ainda mais imprecisa e subjetiva. "Não guardo uma imagem nítida do seu rosto, talvez, ao reencontrá-la agora, não a reconheceria. No entanto, quando os ventos sopram desfavoráveis, regresso a esta cidade com o propósito secreto de encontrá-la" (03min.23seg.), afirma José Luís, o narrador. Diante da impossibilidade de lembrar algo mais, é o momento presente do personagem no seu processo de busca que se torna essencial no filme. 


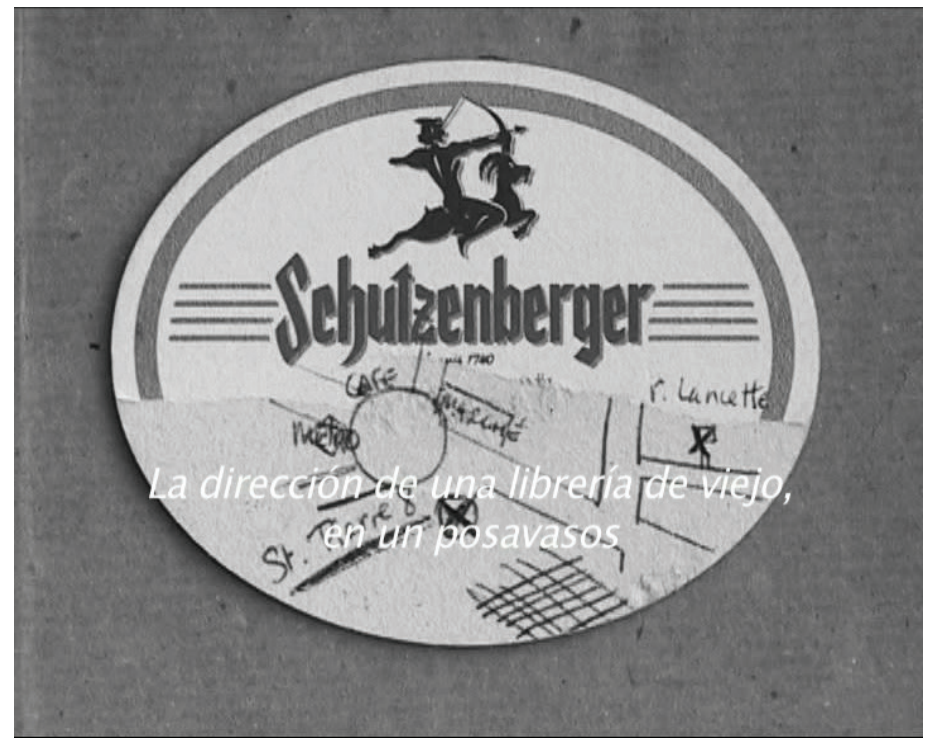

Imagem 01 - Fotograma de Unas fotos en la ciudad de Sylvia

Unas fotos en la ciudad de Sylvia compartilha da premissa construída pelo filósofo Henri Bergson de que "é do presente que parte o apelo ao qual a lembrança responde, e é dos elementos sensóriomotores da ação presente que a lembrança retira o calor que the confere vida" (BERGSON, 2010, p.179). É a ação presente que origina e determina o transcorrer do processo de rememoração, como um ato que está longe de ser passivo ou mecânico, uma vez que confronta diretamente as imperfeições da situação de recordar algo.

Nesse filme-diário, o objetivo vai além de conseguir ou não encontrar Sylvia e termina por despertar um processo de evocações da lembrança que originou o filme. "Em cada esquina a desaparecida é lembrada. Esta busca conduz meus passos. Busco um rosto em uma cidade, uma figura em um entorno" (34min.27seg.). Cada rosto que encontra nas ruas de Estrasburgo tem uma potencial Sylvia, cada retrato fotográfico captado tem uma evocação de Sylvia (Imagem 02). Diante de tamanhas imprecisões que impossibilitam uma busca mais direcionada, o que interessa em Unas fotos en la ciudad de Sylvia é o processo de busca de José Luís Guerín frente a sua própria memória a cada vez que se depara com novos rostos "na cidade de Sylvia". Nesta 


\section{Contracampo}

rememoração errante, vaga, imprecisa, Guerín estabelece passagens, fluxos, abre caminhos entre as suas lembranças precedentes e as lembranças que são geradas por essa busca, pelo registro fotográfico que revela o seu processo.

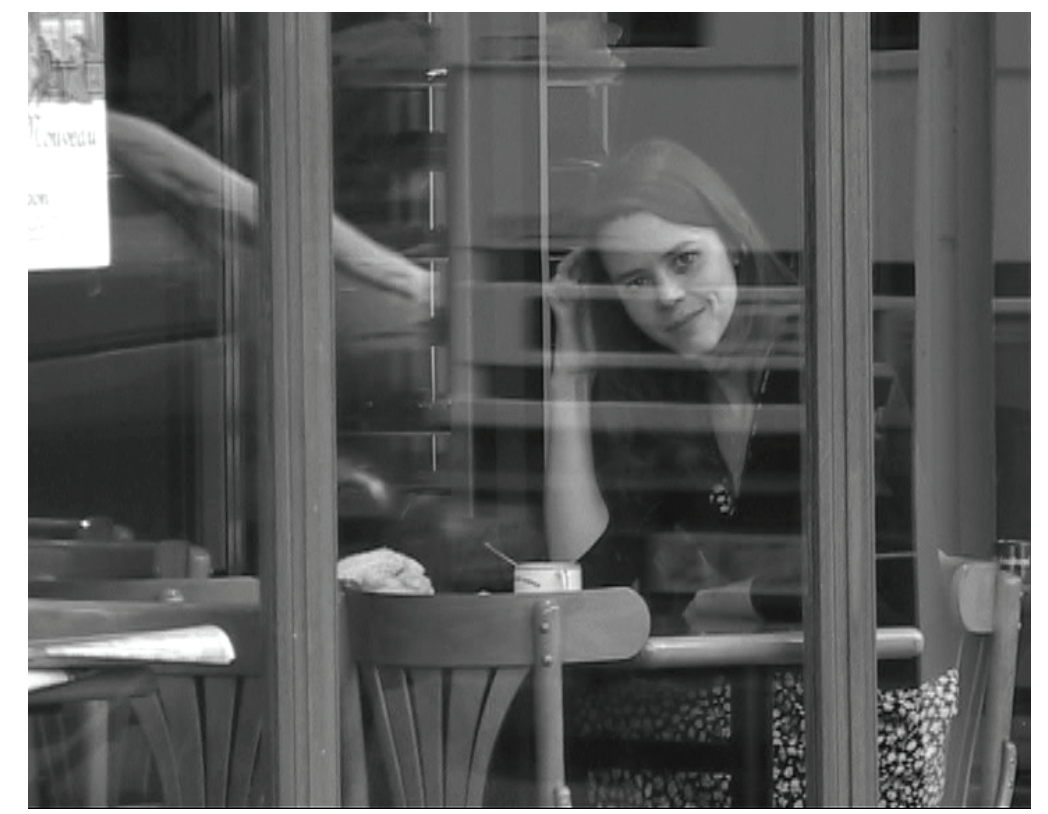

Imagem 02 - Fotograma de Unas fotos en la ciudad de Sylvia

Em Unas fotos en la ciudad de Sylvia "o regresso do passado não é sempre um momento liberador da lembrança, mas um advento, uma captura do presente" (SARLO, 2005, p.09). O fato de não alcançar o seu ponto de chegada, ou seja, de não encontrar Sylvia, fez deste caminho de buscas dentro do filme, um fim em si mesmo. Sylvia é a busca do narrador José Luís pelo seu próprio ato em rememorar algo, o desejo por entender como operam estes mecanismos de escavar as suas próprias lembranças, tendo em vista um passado que se encontra inalcançável e o quanto o momento presente interfere nesta construção.

\section{O filme como escavação de uma memória}

No limiar entre o esquecimento e a conservação, se constroem arquivos, escritas, registros audiovisuais que revelam a construção de suportes de memória. Ciente da fragilidade das recordações frente à 
passagem do tempo, o homem cria meios para manter, armazenar, não esquecer as suas vivências.

(...) a escrita não é só medium de eternização, ela é também um suporte da memória. A escrita é, ao mesmo tempo, medium e metáfora da memória. O procedimento da anotação e da inscrição é a mais antiga e, através da longa história das mídias, ainda hoje a mais atual metáfora da memória. (ASSMANN, 2011, p.199)

O próprio ato de escrever se torna assim um ato de rememorar, de fazer pulsar a memória, sem deixar que ela possa desvanecer no esquecimento. Neste exercício de subjetividade, a escrita se transforma, então, em um lugar de memória, na construção de arquivos que se tornam documentos que podemos recorrer diante de lembranças que fogem ao nosso domínio. "Cada dia anotado é um dia preservado. Dupla e vantajosa operação. Assim, vivemos duas vezes. Assim, protegemo-nos do esquecimento e do desespero de não ter nada a dizer" (BLANCHOT, 2005, p.273).

Na obra de Guerín, o registro audiovisual se afirma como a construção de uma memória, como testemunho de um processo tanto do realizador, como de um meio coletivo (povoados, grupo de pessoas), em um determinado local. É o que acontece, por exemplo, no documentário En construcción (2001), onde Guerín, em conjunto com seus alunos do curso de mestrado em Documentários de Criação da Universidad Pompeu Fabra, decidiu registrar durante o período de dois anos, a transformação do bairro El Raval, em Barcelona. Conhecido como "barrio chino", o que o filme documenta não é somente as histórias dos personagens que vivem neste local, mas também o processo de transformação urbanística que viveu este tradicional bairro barcelonês, que no final dos anos 90, começou a ceder espaço para a construção de novos edifícios.

Os registros de En construcción testemunham assim um processo de transformações e de embates entre o passado e o presente, entre uma memória coletiva e uma projeção de futuro. Não por acaso, Guerín inicia esse documentário com imagens de arquivo antigas do bairro, 
das suas ruas e de seus cafés. Essas imagens ganham um considerável contraste diante do trabalho das escavadeiras e demolições de prédios antigos nesse mesmo local durante os anos de 1998 a 2000, mostradas no filme. Nesse contexto, as próprias imagens de arquivo passam a serem vestígios de um período que naquele momento estava perdendo os seus referenciais com a modernização urbana que estava por vir. Ao partir da delimitação de um local, Guerín sai em busca dos vestígios de uma memória coletiva deste espaço. Como ele mesmo afirma, em depoimento para Víctor Paz Morandeira:

Um filme que me entusiasma é Nuit et brouillard (Alain Resnais, 1955), que está construído assim: como explicar o que passou nos campos a partir de um olhar sumamente objetivo, que busca signos, vestígios, nas distintas dependências do local, que o encara como um material muito objetivável e palpável. Esses signos são provas evidentes, como os vestígios das unhas que ficaram incrustadas no concreto das câmeras de gás. Para mim, essa tem sido sempre uma orientação: passear e observar. Me estimula outorgar um valor semântico aos vestígios que ficam em uma paisagem. (MORANDEIRA, 2011)

Mas En construcción consegue ir além quando estabelece uma ponte ainda mais ampla sobre os vestígios que começam a ser encontrados com o avanço destas obras. Em meio ao processo de construções e demolições são descobertas ossadas de humanos nos subterrâneos do bairro, identificados por arqueólogos como pertencentes ao Império Romano, do século V d.C. (Imagem 03). Durante uma longa sequência de aproximadamente vinte minutos, Guerín se detém a mostrar tanto o trabalho dos arqueólogos em escavar e limpar os ossos, como também na reação das pessoas que passam pelo local, impressionadas diante de tal descoberta. 


\section{Contracampo}

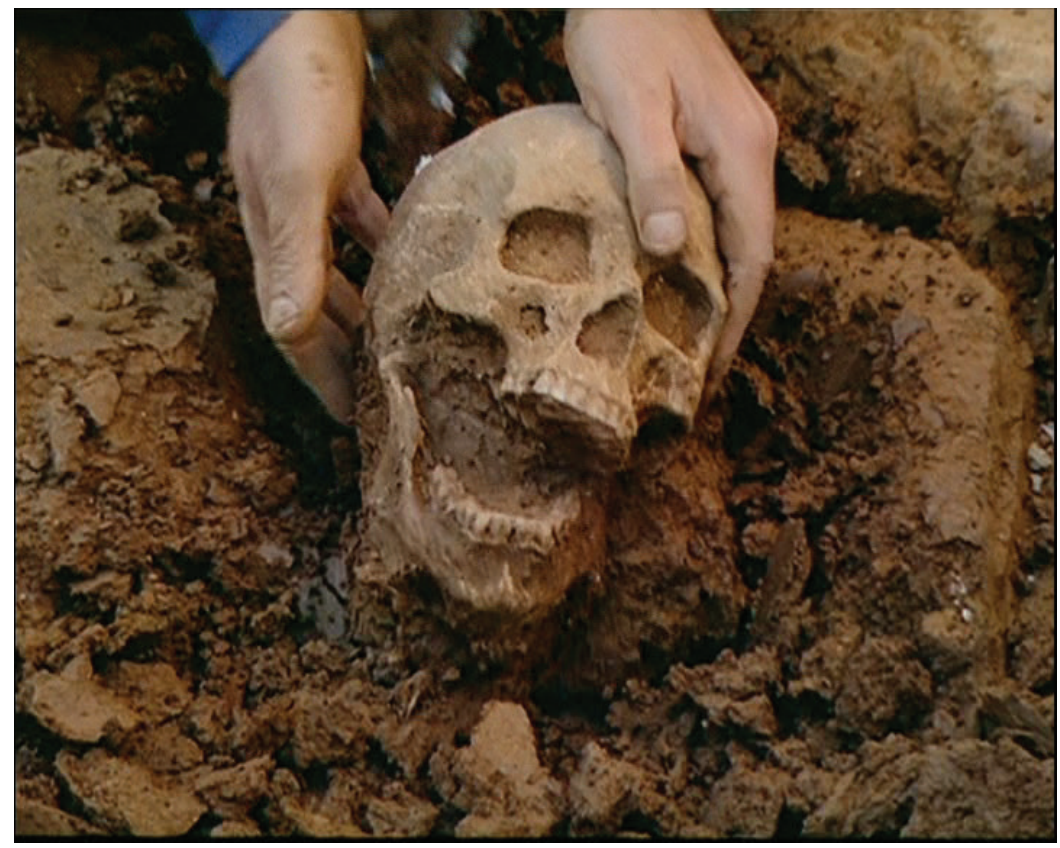

Imagem 03 - Fotograma de En construcción

O documentário possui o mérito de documentar não somente o fato em si (a descoberta das ossadas), mas também captar a limiaridade da situação: ao se construir um futuro, descobre-se o passado de forma involuntária. Diante dos olhares surpresos das pessoas sobre as ossadas, é revelada a existência de uma memória coletiva que estava soterrada por uma era moderna que pouco consegue remeter ao período romano ao qual pertencem estes corpos (Imagem 04).

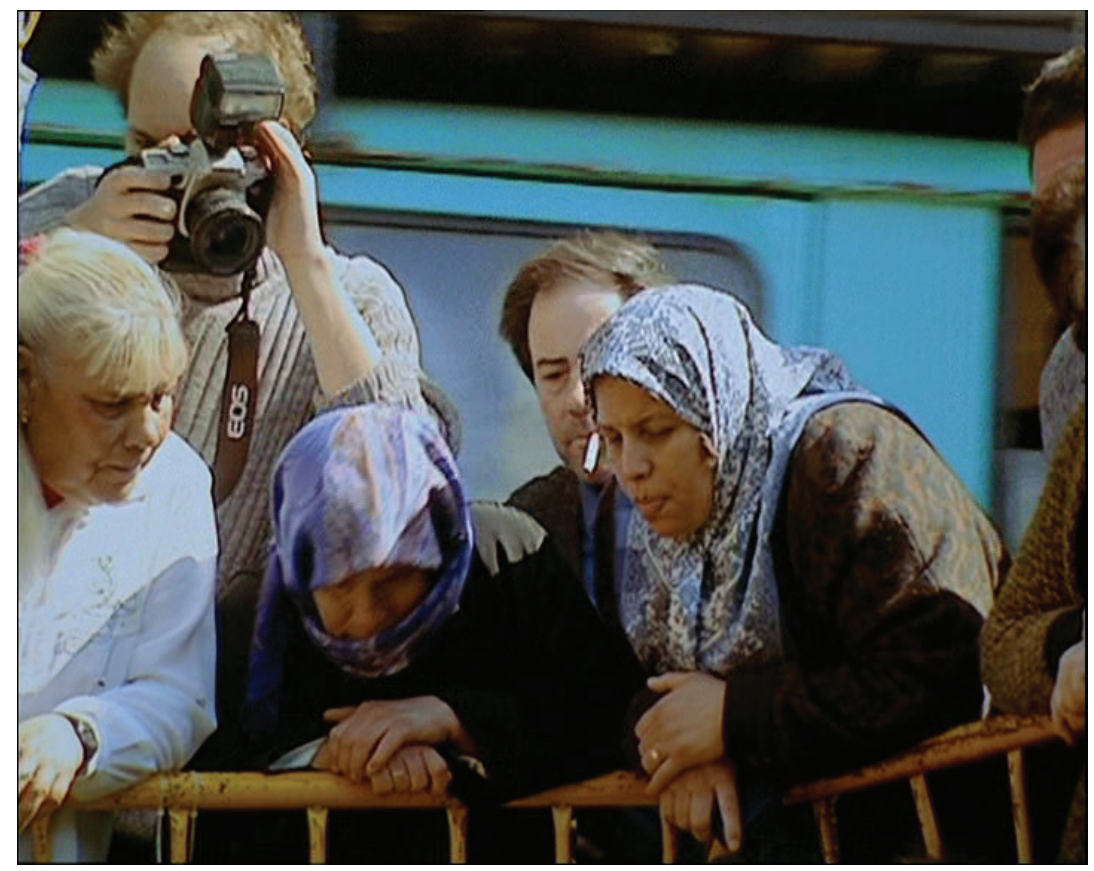


"Esta é uma coisa histórica e não se poderia ter tocado" (23min26seg), diz uma das pessoas que observa o trabalho dos arqueólogos; "incrível que vivemos em cima dos mortos e nem sequer nos inteiramos" (24min23seg), afirma outra senhora, "tomara que encontrem ouro" (25min26seg) diz uma criança. Jovens, crianças, senhores, famílias inteiras projetam suas visões pessoais ao observarem estes vestígios de uma época que desconheciam pertencer a este local. As imagens de En construcción revelam assim um choque temporal entre o presente (a descoberta dos ossos), em relação a uma situação passada (Século $V$ d.C.), tendo-se em vista o futuro (a construção de novos terrenos no "barrio chino").

Não por acaso, essa sequência do filme remete essencialmente a um estado limiar, a uma dobra, a um ponto de inflexão no próprio entendimento sobre a memória do local. Na medida em que este território foi literalmente escavado para além da sua própria superfície, isto também revela algo ainda mais simbólico para o entendimento sobre a relação entre limiaridade e memória. Se tanto Arnold van Gennep como Walter Benjamin buscaram entender a questão do limiar através do simbolismo que uma porta possui no processo de passagem, seja ela como "a porta dos muros do bairro, a porta da casa" (GENNEP, 2008, p.36) ou mesmo "a entrada do trem, da cervejaria, da pista de tênis, dos lugares turísticos" (BENJAMIN, 2005, p.23), o que a sequência de En construcción revela é que o limiar também é construído pelas escavações. Através de um processo, involuntário ou não, de escavar a memória, seja de um local, de um grupo de pessoas ou de um indivíduo, caminhos são abertos para entender determinado contexto a partir de uma nova perspectiva. É neste processo que se revela um estado limiar, um deslocamento de significações que promova um novo entendimento sobre determinada questão.

Norteado por essa ideia, Guerín iniciou sua obra em longa metragem também a partir de um processo de escavação da memória 
coletiva de um povoado no interior irlandês. É o caso do documentário Innisfree, realizado onze anos antes de En construcción. Interessado em saber como se encontram, quase quarenta anos depois, as pessoas e as locações do filme The quiet man (1952), de John Ford, Guerín decidiu ir para o interior da Irlanda para reconstruir este imaginário. A começar pelo contexto que envolve o filme que originou a proposta do documentário, Guerín se encontra novamente em distintas camadas memorialísticas.

A realização de The quiet man, para John Ford, foi a possibilidade não apenas de retornar à terra dos seus antepassados para filmar, como também a concretização de um projeto pensado desde 1937 em que o diretor pretendia resgatar a memória de muitos irlandeses que migraram para os Estados Unidos. The quiet man conta a história de um homem que decide regressar trinta anos depois a sua terra natal depois de partir para os Estados Unidos quando tinha 12 anos de idade. Ao regressar, decide comprar a casa onde viveu na sua infância e os terrenos que a rodeiam, mas para alcançar o seu objetivo terá que enfrentar um fazendeiro local e conquistar o respeito do povoado.

Se por um lado, John Ford fez este filme em busca das suas raízes, da memória dos seus antepassados, José Luís Guerín vai em busca do que a realização deste filme transformou na memória dos habitantes do local. Innisfree é um filme que busca o reencontro de um povoado com a sua própria rememoração, com as lembranças de um momento que transformou a história de seus habitantes. "A filmagem terminou três ou quatro meses antes que eu nasci. É uma lembrança, uma imagem que não somente herdei dos meus pais, mas também dos vizinhos e que transmitirei aos meus filhos" (01h.01min.57seg.), afirma uma das pessoas entrevistadas. "Minha melhor lembrança da filmagem foi ter conhecido essa gente maravilhosa, os bons momentos que passamos juntos e essas noites cantando e dançando. O que mais sinto agora é que eles já não estão vivos" (01h06min.03seg.), afirma outro habitante do povoado.

Décadas depois, permanecem as evocações deste passado. Uma 
das pessoas que participou das filmagens, ainda guarda como relíquia um isqueiro de John Ford (Imagem 05), onde está escrito "Capitan John Ford. Reserva de la Marina en el U.S.S Missouri" (01h.00min.23seg.). Outra pessoa lembra que em uma das festas da equipe, chegou a dançar com a atriz Mauren O'Hara. Em cada depoimento existe um estado de resgate da memória daquelas pessoas que presenciaram as filmagens, assim como um desejo de Guerín em potencializar essa busca.

Mas se já não bastasse encontrar este estado nostálgico, Guerín convoca também as crianças para descrever o argumento de The quiet man e comentarem as partes que acharam mais interessantes do filme. Desprovidas de lembranças, as crianças começam a construir as suas próprias lembranças ao participarem do documentário com seus depoimentos e descobrem as memórias existentes no povoado.

Ao visitar as locações do filme, como a estação de trem de Castletown, o riacho onde os personagens de Sean Thornton (John Wayne) e Mary Kate Danaher (Maureen O'Hara) atravessam felizes por estarem juntos, o bar local onde a equipe do filme se reunia para festejar (e que turistas americanos visitam por terem ainda a referência do filme, como afirma o dono do bar), faz de Innisfree um filme onde os lugares também evocam a reconstrução da memória. Guerín percorre as locações em busca de vestígios do que ainda permanece e do imaginário que se construiu do local através do filme. Mesclando as imagens atuais dos lugares com os sons do filme original, o realizador espanhol também constrói este estado limiar entre o passado e o presente, entre o imaginário do que se construiu e o que permanece no lugar. 


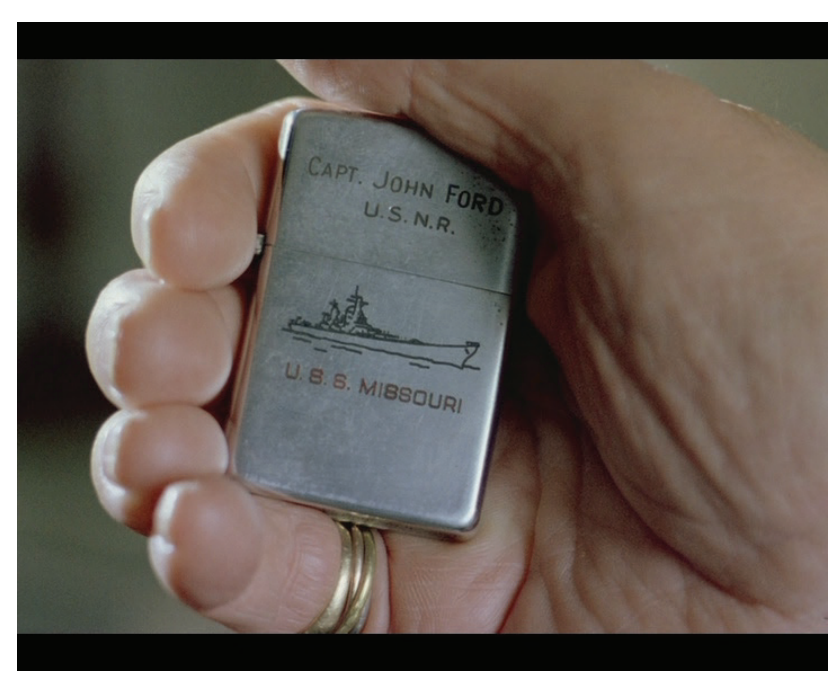

Imagem 05 - Fotograma de Innisfree

O que Guerín consegue evidenciar tanto em Innisfree como En construcción, é o caráter transitório da memória e como essa transitoriedade, através de um processo de escavação, revela limiaridades espaço-temporais. En construcción consegue captar momentos onde um passado até então desconhecido é revelado (como é o caso dos ossos encontrados no bairro El Raval) e termina alterando diretamente o momento presente daquele local (o fato das obras terem sido interrompidas ao descobrirem os restos mortais). Quanto a Innisfree, Guerín faz um filme sobre as lembranças de outro filme e termina revelando como um fato específico (a realização do filme de John Ford) acabou se tornando, desde então, determinante para a construção da própria memória e identidade do lugar.

\section{A imagem como conservação de uma memória}

Os filmes de Guerín revelam um tom fortemente autoral, repletos de deslocamentos estéticos e narrativos, construindo e resgatando memórias. No entanto, no que se refere ao realizador, poucos referenciais autobiográficos são evidenciados. Nesse sentido, assistir a sua obra não é propriamente um desejo em encontrar sua trajetória pessoal, como é possível perceber em autores de filmes-diário, como 
por exemplo, em Jonas Mekas ou David Perlov.

Porém, a partir de 2007, Guerín decidiu aceitar todos os convites de festivais para promover o seu até então último filme, En la ciudad de Sylvia (2007). Deste processo que levou dois anos atravessando territórios como a América do Sul, passando por EUA, Europa e Ásia, nasceu o filme-diário Guest (2010). Com sua câmera de vídeo portátil e sem equipe técnica, Guerín começou a registrar as cidades, as pessoas, os bastidores dos lugares por onde passou. Assumindo uma vez mais o formato de filme-diário que já esteve presente em Unas fotos en la ciudad de Sylvia, Guerín encontrou nos seus registros a construção de uma memória pessoal sobre estes dois anos de viagens.

As imagens de Guest se tornaram, assim, um testemunho do processo de interação de Guerín com outras culturas, de contato com pessoas que ele não conhecia previamente, de incontáveis deslocamentos de um país a outro. Ao mesmo tempo em que buscava conhecer e registrar o outro e desbravar culturas distantes da sua, Guerín também começou a materializar em imagens, a construção da sua memória pessoal sobre esse período. Se o formato diário, seja literário ou cinematográfico, se constitui como o lugar por excelência de retenção da memória contra o esquecimento, da escrita diária de pequenas vivências cotidianas como suporte de lembranças, Guest revela o desejo de Guerín por não deixar escapar as experiências vividas durante os dois anos de viagens.

Deste material registrado, Guerín também aproveitou para utilizar parte dele em outro projeto. Intitulado Correspondências (2011), e patrocinado pelo Centro de Cultura Contemporánea de Barcelona (CCBB), Centro Cultural Universitário Tlatelolco (CCUT-UNAM, México), La Casa Encendida de la Obra Social de la Caja Madrid e Acción Cultural Española $(A C / E)$, este projeto propôs a dez realizadores divididos em cinco duplas ${ }^{2}$, que realizassem ao longo de um ano, trabalhos de correspondência em formato de vídeo-cartas. A Guerín coube se

2 José Luis Guerin-Jonas Mekas, Albert Serra-Lisandro Alonso, Isaki Lacuesta-Naomi Kawase, Jaime Rosales-Wnag Bing, Fernando Eimbcke-So Yong Kim. 
corresponder com Jonas Mekas, fator este que resultou em nove vídeocartas, com aproximadamente dez minutos de duração cada. Nestes vídeos, um em especial chama a atenção quanto à questão da memória: a vídeo-carta número três, realizada por Guerín em maio de 2010.

Nessa vídeo-carta, Guerín apresenta uma moça eslovena chamada Nika Bohinc, que conheceu num festival de cinema de Lisboa, através de uma entrevista que ela realizaria com o diretor espanhol. Se era para ele ser o entrevistado, as imagens de Guerín revelam que ele acabou se tornando o entrevistador. Num determinado momento, ele pergunta se ela se lembra da primeira vez que foi ao cinema. Nika logo responde: "Sim, claro que me lembro. O primeiro filme que fui ver com meus pais foi Branca de neve. Não me lembro, mas me contaram que eu chorava tanto que tiveram que me tirar do cinema" (06min.56seg.) Nas imagens transparecem a sintonia entre ambos, além de revelar ternura, sinceridade, inquietações de uma jovem com menos de trinta anos e "com um destes olhares que nos ajudam a fazer filmes, a fazer cinema", como afirma Guerín no vídeo.

Mas ao final desta vídeo-carta, o choque. Guerín informa que Nika e o seu companheiro (Alexis Tioseco), assim que foram viver em Manila (Filipinas), foram assassinados no dia primeiro de setembro de 2009, em decorrência de um delito gerado por um grupo de delinquentes. As imagens de Guerín automaticamente levam o espectador a uma outra reflexão: o impacto da informação que fecha o vídeo, somado ao olhar final de Nika para Guerín (Imagem 06), revelam um sentimento de incomodo. Frente à morte, permanecem vivas as imagens. Frente à impossibilidade de Guerín em reencontrá-la novamente, permanecem os vestígios, a vivacidade de um encontro que já aconteceu e que não se repetirá mais. 


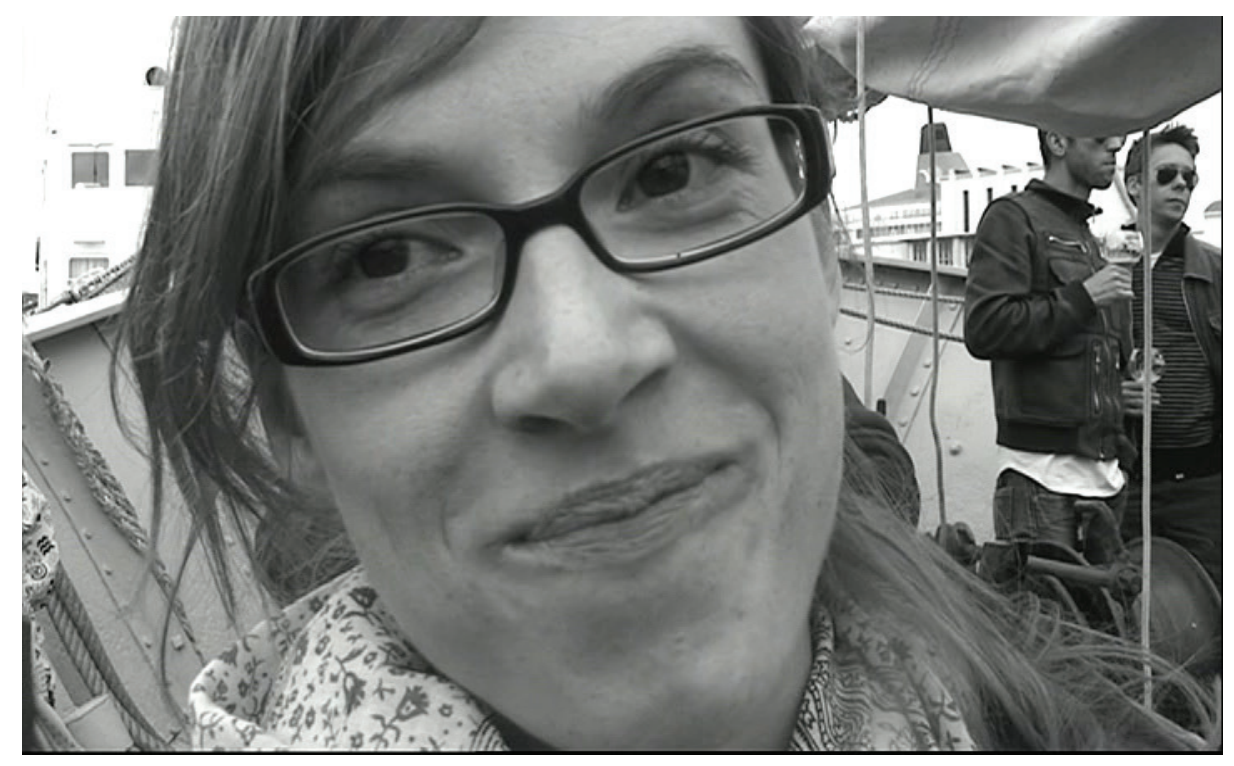

Imagem 06 - Fotograma de Correspondências

O olhar de Nika em direção a câmera se desdobra, vida e morte compartilham um mesmo estado limiar, uma mesma imagem. Frente à finitude da vida, essas imagens se tornam guardiães de uma memória. Ao rememorar esse encontro, Guerín nos confronta com a fugacidade da vida. Sua escolha por trazer a informação trágica ao final do vídeo acaba intimando uma reflexão sobre o sentido da imagem enquanto memória, pois se as imagens permanecem para nos lembrar da passagem do tempo, da fragilidade da nossa existência, também revelam "o embalsamento do tempo" (BAZIN, 1991, p.24), uma materialidade que procura reter a memória diante da ação inevitável do tempo.

\section{Considerações finais}

Realizar um ato de rememoração é desencadear um processo de deslocamentos. Neste caminho se constroem inflexões, escavações, se promovem estados limiares entre a lembrança e o esquecimento, entre a evocação de uma lembrança e os seus vestígios. Pensar o ato de rememoração desde a perspectiva da sua limiaridade contribui assim para se pensar o quanto a passagem do tempo interfere na 
própria construção da memória e no momento presente em que se busca rememorar.

É partindo destes apontamentos e análises feitos ao longo deste artigo, que a obra de José Luís Guerín ganha relevo. Seus filmes revelam a vitalidade contida no ato de rememorar, de encontrar nas nuances dessa situação, um caminho atravessado por fluxos e desvios. Seus personagens são construídos pela memória, se alimentam dela para existirem, como é o caso de Unas fotos en la ciudad de Sylvia. Ou então descobrem com espanto que uma memória coletiva estava logo debaixo dos seus pés, sem nunca antes terem conseguido perceber isto, como expõe En construcción. A memória também pode se tornar algo para ser repassado de geração em geração, como revela Innisfree, ou, então, se afirmar como um simples registro cotidiano na busca pelo outro, como ocorre em Guest.

Os filmes de Guerín revelam assim a um estado limiar contido no ato de rememoração, do seu lugar de evocação até a sua luta contra o esquecimento, passando por um caminho de descobrimentos e/ou reconhecimentos. De Innisfree a Guest, sua obra ganha transcendência para se pensar no estado transitório e frágil da memória, mas também para entender como as imagens são intermediarias e artífices deste processo.

\section{Referências}

ASSMANN, Aleida. Espaços da recordação: formas e transformações da memória cultural. Campinas, SP: Editora da Unicamp, 2011.

BAZIN, André. O cinema - ensaios. São Paulo: Brasiliense, 1991.

BENJAMIN, Walter. Libro de los pasajes. Madrid: Ediciones Akal, 2005.

BERGSON, Henri. Matéria e memória. São Paulo: Martins Fontes, 2010.

BLANCHOT, Maurice. O livro por vir. São Paulo: Martins Fontes, 2005.

GAGNEBIN, Jeanne Marie. Limiar, aura e rememoração. São Paulo: Editora 34, 2014.

GENNEP, Arnold van. Los ritos del paso. Madrid: Alianza Editorial S.A., 2008. 
MATOS, Olgária. "Pórticos e passagens: Walter Benjamin - Contratempo e história". In: MACHADO, Carlos Eduardo Jordão; MACHADO JR., Rubens; VEDDA, Miguel (orgs.). São Paulo: Editora Unesp, 2015. p.99-114.

MORANDEIRA, Víctor Paz. Entrevista a José Luís Guerín (Parte 1), 2011. Disponível em: http://www.acuartaparede.com/entrevista-jose-luis-guerin$1 /$ ?lang $=$ es

ROSSI, Paolo. O passado, a memória, o esquecimento: seis ensaios da história das ideias. São Paulo: Editora UNESP, 2010.

SARLO, Beatriz. Tiempo passado - Cultura de la memoria y giro subjetivo. Una discusión. Buenos Aires: Siglo Veintiuno Editores, 2005. 